\section{A MAGYARORSZÁGI BIZTOSITÁSI PIAC - \\ AKADÉMIKUS SZEMMEL GILYÉN ÁGNES BESZÉLGETÉSE DR. BÉLYÁCZ IVÁNNAL}

Gilyén Ágnes (Magyar Biztositók Szövetsége) agnes.gilyen@mabisz.hu

\section{ÖSSZEFOGLALÓ}

Az alábbi interjú dr. Bélyácz Ivánnal készült. Iván 1971-ben szerzett közgazdász diplomát Budapesten. A Pécsi Tudományegyetem oktatója, egyetemi tanár, a Gazdálkodástani Doktori Iskola vezetője, a Magyar Tudományos Akadémia rendes tagja. Kutatási területe a vállalati pénzügyek, a befektetések és a kockázat elméleti problémái. Számos befektetési tárgyú könyv és tanulmány szerzője.

\section{SUMMARY}

Iván Bélyácz graduated at the Budapest University of Economics, in 1971. He actually serves as a Professor of Finance at Faculty of business and Economics of Univesity of Pécs. He is head of Doctoral School of Business and Economic studies and he is an ordinary member of Hungarian Academy of Sciences. His research fields are: Corporate Finance studies, Investment and Risk Theory. He is author of many books and articles on the investment area.

Kulcsszavak: biztosítási piac, biztosítási trendek

JEL: G22

Key words: insurance market, trends in insurance business

JEL: G22

DOI: $10.18530 /$ BK.2015.4.12

http://dx.doi.org/1018530/BK.2015.4.12
Ön vaskos kötetet írt „Befektetési döntések megalapozása” címmel, amelyből a jövő közgazdásznemzedéke is tanul az egyetemeken. Az elmúlt negyedszázad ismeretében jó döntést hozott az, aki 25 évvel ezelőtt tőkebefektetőként belépett a magyarországi biztosítási piacra?

Egyértelmüen igen. Emlékezetes, hogy a nyolcvanas évek végén, a rendszerváltás környékén már nem is monopólium, hanem duopólium jellemezte a magyarországi biztosítási piacot. A piac kinyitásával, illetve a privatizáció megindulásával olyan nagy reputációjú osztrák, német, amerikai, francia cégek jöttek be a magyarországi biztosítási piacra, amelyek belépése, az általuk hozott know-how nagyon komoly nyereség volt az egész hazai pénzügyi rendszer számára. Ennek jelentősége különösen fontos annak ismeretében, hogy a biztosítási piacon az erős tőkeháttér, a stabilitás, a biztonságos és kiegyensúlyozott gazdálkodás alapvető feltétel. Ezt tudták behozni a magyarországi piacra belépő nagy nemzetközi cégek.

Ugyanakkor abban, hogy a kis biztosítók anyacégei mennyire lehetnek ma elégedettek, már bizonytalanabb vagyok. Több kisebb biztosító is veszteséges, és való igaz, hogy a nagy biztosítók már az első években, a 90-es évek elején jelentős piaci részesedést szereztek.

Én úgy látom, mintha kissé túl sok lenne erre a kis piacra a 30 biztosító. Mint ahogy a bankpiacon is sok volt - még a válság kitörése előtt - a 40-42 bank. Gyakran hivatkoznak arra, hogy például a szomszédos Ausztriában, egy alig 8 milliós piacon mennyivel több a biztosító, és meg tudnak élni, azt azonban nem szabad elfelejteni, hogy a rentábilis működésre képes pénzügyi intézmények számát inkább a gazdaság teljesítménye, kevésbé a lakosok száma határozza meg.

Mint a hazai privatizáció történetének avatott szakértője és a privatizációs metodikával foglalkozó kézikönyv szerkesztője, illetve szerzője, milyennek találja utólag a hazai biztosítási szektor privatizációját? Ezt a piacot - ellentétben a bankpiaccal - gyakorlatilag egy fillér állami forrás nélkül tudták konszolidálni, aminek viszont az volt az ára, hogy az állami biztosító(k) külföldi kézbe kerülttek. Mennyire volt kockázatos ez a megoldás?

Én a magam részéről nem fetisizálnám az állami, illetve a nemzeti tulajdont. A tulajdonosok a gazdasági racionalitás talaján állnak, annak alapián hozzák meg döntéseiket, és ilyen értelemben mindegy, hogy hazai vagy külföldi a tulajdonos.

A biztosítási szektort valóban nem kellett állami pénzen konszolidálni, ez tény. Igaz továbbá, hogy ugyanebben az időszakban a bankrendszer rendbetétele mintegy 800 milliárd forint állami forrást emésztett fel. Nem szabad azonban elfelejtenünk, hogy ennek az összegnek csupán a fele volt olyan teher, amelyet az előző rendszerből hoztak magukkal a bankok, így a felhasznált állami pénzzel, a bankrendszeren keresztül, gyakorlatilag magát a vállalati szektort konszolidálták. A másik, mintegy 300-400 milliárd forintnyi hiány az 1990-1994-es évek felelőtlen, laza hitelezésének volt a következménye, illetve annak, hogy 1992-ig a szabályozás, illetve annak hiánya is lehetővé tette, hogy sokan eredeti tőkefelhalmozásra használják az alulszabályozott pénzintézeti hitelezést. 
Ilyen szempontból a biztosítás maga egészen más terület, mivel ez a szektor „tiszta lappal” indulhatott, az intézményrendszer jellegéből fakadóan nemcsak hogy önfinanszírozó a szektor, hanem jelentős díjtartalékot is képez, amellyel aztán intézményi befektetőként jelenik meg a tőkepiacokon.

\section{Egyetemi tanárként hogyan látja a jövő biztosítási szakembereinek képzését?} Megfelelőnek tartja-e?

Túl kevés helyen és kis létszámban képeznek ma Magyarországon biztosítási szakembereket, aktuárius képzés mindössze két helyen, a Budapesti Corvinus Egyetemen és az ELTE-n folyik. Véleményem és tapasztalataim szerint több egyetemen és nem utolsósorban többféle szakon kellene ilyen szakembereket képezni, ahogy erre egyébként igen jó külföldi példákat is találunk.

Ön szerint milyen hatással lehet a gazdasági környezet növekvő bizonytalansága a magyarországi biztosítási szektorra?

Egyértelműen hátrányos. A fundamentális bizonytalanságoknak igen nagy a pénzügyi rendszerre gyakorolt hatásuk, a pénzügyi válság megmutatta, hogy mekkorát lehet bukni akár ebben a szektorban is.

Szerte a világon nagy volt a késztetés arra, hogy a banki és biztosítási szektort - bankbiztosítóként - összevonják, ennek azonban hatalmas a kockázata.

Ma már szerencsére inkább az a tendencia, hogy ezeket a területeket szétválasztják, a korábbinál jóval átláthatóbb működést írva elő számukra. A biztosítási területet a Szolvencia II. szabályozása a korábbinál sokkal biztonságosabb működés irányába viheti.

\section{Túl kevés helyen és kis létszámban képeznek ma}

Magyarországon biztosítási szakembereket.

Az alacsony kamatszint behatárolja a biztosítók befektetéseken elérhető hozamait. Egyes üzletágak ugyanakkor biztosítástechnikailag veszteséget okoznak a társaságoknak, amelyek így csak a díjak, díjtartalékok befektetéseinek, azok hozamainak köszönhetően nem termelnek veszteséget. Hosszabb távon hogyan befolyásolhatja az alacsony hozamkörnyezet a szektor müködését?

Egy-másfél évtizede tart már a jelenlegi, abnormálisan alacsony kamatszint. Ennek magyarázata, hogy a globális pénzügyi csatornákon már huzamosabb ideje forrásbőség mutatkozik, aminek az lehet a következménye, hogy nem lesz olyan ösztönző erő, amely a lakosságot megtakarításra késztesse. Nehéz kérdés, hogy vajon meddig tartható fenn a jelenlegi alacsony kamatkörnyezet, abban azonban biztos vagyok, hogy egészségtelen jelenség. Bár a gazdaság szempontjából a kamatoknak nincs olyan kardinális szerepük, mint sokan gondolják, az igaz, hogy sokkal egész- ségesebb a 4-5 százalékos reálkamat. Az irreálisan alacsony kamatszint új jelenség, 30-50 éve ilyennel még nemigen lehetett találkozni, és ez jelenség a „moral hazard” irányába viheti el a piacokat.

Egyetemi tanárként, közgazdászként, illetve a Magyar Tudományos Akadémia tagjaként széles körủ rálátással rendelkezik az európai gazdaságokra. Mik okozhatják az európai gazdaságok legnagyobb kihívásait a következő években/évtizedekben?

A következő évtizedekről nem mernék nyilatkozni. Ami a következő éveket illeti, a legnagyobb kihívás a környezetvédelem, a természeti erőforrások kiapadása, illetve a klímaváltozásra adandó megfelelő válasz megtalálása lesz. Hatalmas feladatot jelent a terrorizmus megfelelő kezelése, illetve a nemzetközi konfliktusokra adandó válaszok.

Az európai régiót emellett már most is erősen megterheli a lakosság elöregedésével kapcsolatos feladatok kezelése, az, hogy az átlagéletkor kitolódásával arányosan jóval rövidebb idő jut az emberi életpálya aktív, felhalmozási időszakára, és hosszabb az inaktív szakaszra. Emellett pedig tény, hogy a rendszert nem táplálja megfelelő mértékben a friss, a rendszerbe újonnan belépő munkaerő.

\section{Igen fontos, hogy a biztosításügy rendelkezzen}

tudományos igényü lappal.

Számtalan publikációval a háta mögött kérték fel Önt a Magyar Biztosítók Szövetsége "Biztosítás és Kockázat” címủ új, tudományos folyóirat Tudományos Tanácsadó Testïlete tagjának. Mennyire lehet képes egy folyóirat arra, hogy tudományos szintre emelje a gazdaságnak egy olyan, nagyon is „gyakorlatias” területét, mint a biztosításügy?

A már eddig megjelent írások választ adnak erre. Véleményem szerint igen fontos, hogy a biztosításügy rendelkezzen tudományos igényü lappal, és csak sajnálhatjuk, hogy eddig ilyen nem létezett.

Milyen trendek, tendenciák látszódnak - ha egyáltalán látszódnak - a gazdasági-pénzügyi tudományos folyóiratok hazai és nemzetközi „piacán”? Mennyire simulnak bele a nemzetközi trendekbe a hasonló témájú hazai folyóiratok?

A fejlettebb piacokon lényegesen nagyobb számban jelennek meg hasonló, komoly, tudományos igényű folyóiratok. E területen bőven van még tennivaló, de - szerencsére - a felzárkózás folyik. 